\title{
STUDIES ON THE CUMACEA (CRUSTACEA, MALACOSTRACA) OF JAPAN. PART I.
}

\author{
$\operatorname{AUTHOR}(\mathrm{S}):$ \\ Gamo, Sigeo
}

\section{CITATION:}

Gamo, Sigeo. STUDIES ON THE CUMACEA (CRUSTACEA, MALACOSTRACA) OF JAPAN.

PART I.. PUBLICATIONS OF THE SETO MARINE BIOLOGICAL LABORATORY 1967, 15(2): 133 163

ISSUE DATE:

1967-09-11

URL:

http://hdl.handle.net/2433/175460

RIGHT: 


\title{
STUDIES ON THE CUMACEA (CRUSTACEA, MALACOSTRACA) OF JAPAN. PART I.
}

\author{
SIGEO GAMÔ \\ Faculty of Education, Yokohama National University, Yokohama
}

With 11 Text-Figures

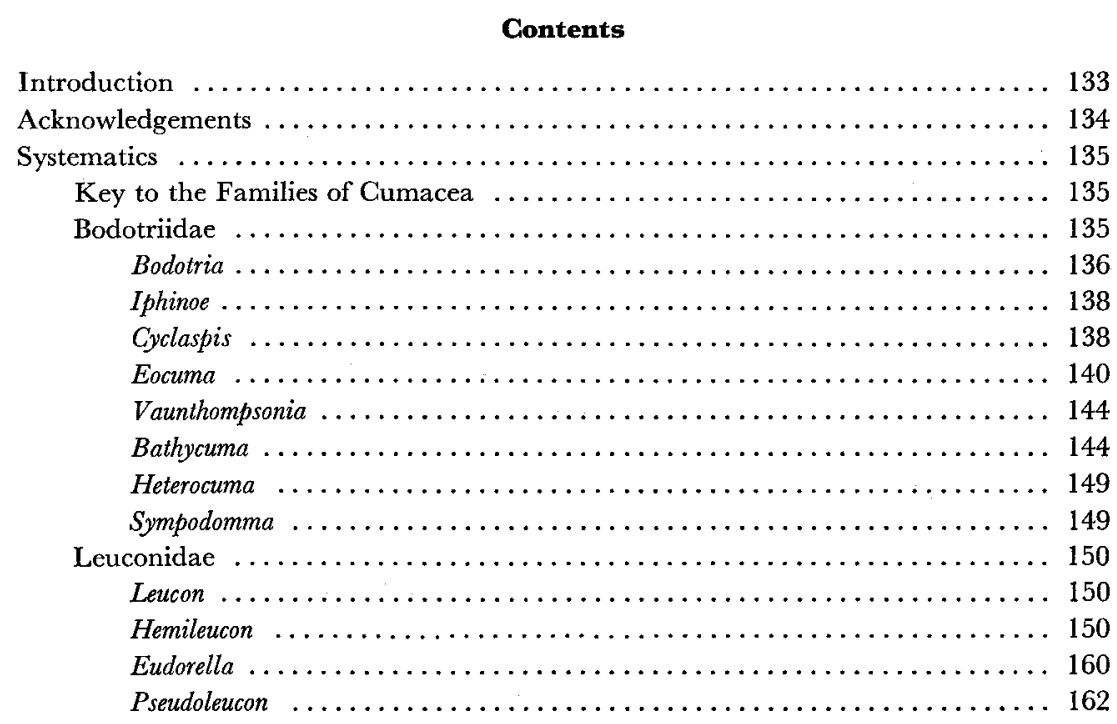

Introduction

The first record of Cumacea from Japanese waters-Heterocuma sarsi Miers and H. sarsi var. granulata Miers-was made by Miers in 1879 and then in 1894 Eocuma hilgendorfi Margusen was described by Hilgendorf and Marcusen from Enosima in Sagami Bay. Subsequently important contributions were made by Zimmer (1903, 1921, 1943) and Calman (1912). Further remarkable advance in knowledge of cumaceans from Japan and its adjacent waters was due to the works by Zimmer (1902-1952), Calman (1907, 1910, 1911, 1912), Derzhavin (1923, 1926), Fage (1945), Uéno (1933, 1934), Lomakina (1952-1960) and Marukawa (1927), etc. Recently additional contributions are made by Gamô (1958-) and Harada (1959-). On the other hand, many of papers have been published by Hale (1928-

Publ. Seto Mar. Biol. Lab., XV (2), 133-163, 1967. (Article 8) 
1953 a) on the Australian Cumacea, by Jones (1963) on the Cumacea of the New Zealand, by Kurian (1951, 1954-) on the Indian Cumacea, and by Given (1961, 1964-) on the Californian Cumacea, etc.; some species described in these papers may be found in Japanese waters, too, by further studies.

Historically Stebbing's systematic work of the Cumacea appeared in "Das Tierreich" (1913) has been most useful for identification of the species, though his system of classification was not generally accepted. While, the general account of the order given by Zimmer (1941) in "BronN's Klassen und Ordnungen des Tierreichs" has been accepted by many authors.

At present 96 species (including 13 species newly recorded in this paper) referable to 24 genera and 5 families are described from Japan. Most of the species have been collected from the shallow waters by sub-surface night towing of plankton-net, dredging, bottom-sampling, or by skimming the surface layer of the sandy or muddy substratum near the low tide mark. The fresh samples obtained by various methods mentioned above may be treated little by little in the following way. A small part of the sample is taken in a shallow dish containing sea-water. Cumaceans and other small animals will swim out when the contents of the dish are stirred or they will be gathered to the light when the dish is exposed to an electric lamp. Cumaceans may be collected rapidly by pipette and kept in a small vial or dish with fresh seawater. In this way, even very small species can be easily detected and distinguished from other animals, such as copepods, amphipods, etc., as the body shape and the mode of swimming of cumaceans are very characteristic and peculiar enough. This sorting method is available not only to smaller cumaceans but also to other small animals occurring in plankton or in soft sediments. Other methods of collecting cumaceans are given in the works by Sheard (1941), Zimmer (1941), Băcescu (1951), FAGe (1951), Hale (1953a) and Jones (1963), etc. So far, only a few cumaceans are obtained from the depth of $1,000 \mathrm{~m}$ or more in Japanese waters. By further investigations, especially of the deeper water, a remarkable increase of species can be expected.

The present paper includes keys to the families, genera and species of the Cumacea of Japan and a brief account is provided to each species. The order adopted here is mostly followed after Zimmer (1941), FAGE (1951) and Jones (1963).

\section{Acknowledgements}

I wish to express my gratitude to Professor Tune SAKaI of the Yokohama National University for his kindness in giving me this opportunity of studying Japanese cumaceans and then in guiding me in the course of the study. Also I am greatly indebted to Professor Sadayoshi Mryake of the Kyushu University for his kind advice and encouradgement. I must express heartily my indebtedness to Professor Masao Iwasa of the Seikei University, Professor Huzio Utinomi and Associate Professor 
Tokasi Tokioka of the Seto Marine Biological Laboratory of the Kyoto University for their invaluable advice. My grateful thanks are due to Dr. Tadashige Habe of the National Science Muscum, Tokyo and Dr. Taiji KIKuchi of the Amakusa Marine Biological Laboratory of the Kyushy University and Dr. Makoto OMoRI of the Ocean Research Institute of the University of Tokyo for the specimens which they kindly offered me at my disposal for identification. "Further, I also wish to express my particular thanks to other many persons who helped me in many ways in the course of the present work.

\section{Systematics}

Key to families of Cumacea

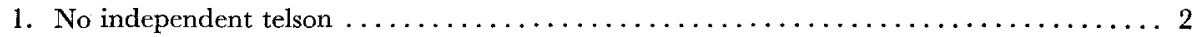

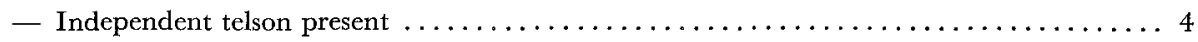

2. Mandibles normally boat-shaped with molar process cylindrical, or sometimes widened at the base and with molar process styliform $\ldots \ldots \ldots \ldots \ldots \ldots \ldots \ldots \ldots \ldots$

- Mandibles broadly truncated at the base with molar process cylindrical .... Leuconidae

3. Male usually has 5 pairs of pleopods, exceptionally 2 or 3 pairs. Endopod of uropods has

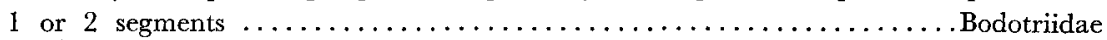

- Male without pleopods. Endopod of uropods one-segmented ........... Nannastacidae

4. Male has 5 pairs of pleopods and 3 pairs of exopods. Endopod of uropods has only one segment

(Ceratocumidae)

- Male has 3 pairs of pleopods or none, and 5 pairs of exopods $\ldots \ldots \ldots \ldots \ldots \ldots \ldots$

5. Telson well developed with at least 3 end spines $\ldots \ldots \ldots \ldots \ldots \ldots \ldots$ Lampropidae

- Telson well developed or small, with 2 end spines or none $\ldots \ldots \ldots \ldots \ldots \ldots \ldots 6$

6. Endopod of uropods has only 1 segment, male has 5 pairs of exopods ....(Pseudocumidae)

- Endopod of uropods has 2 or 3 segments or non-segmented. Male has 2 pairs of pleopods or none. Telson relatively large and with end spines $\ldots \ldots \ldots \ldots \ldots \ldots$ Diastylidae

\section{Family Bodotriidae T. Scotr, 1901.}

Key to sub-families and Japanese genera of Bodotriidae

1. At least first two pairs of peraeopods with well developed or rudimentary exopod in either sex $\ldots \ldots \ldots \ldots \ldots$ (Sub-family Vaunthompsoniinae HALE, 1944) ...5

- Only the first pair of peraeopods with exopod.......... Sub-family Bodotriinae

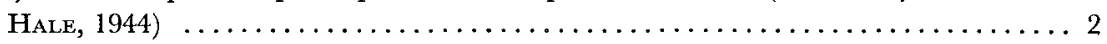

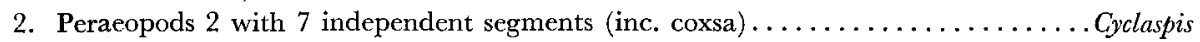

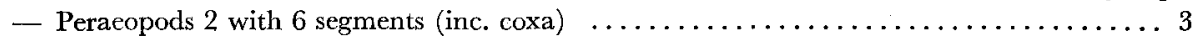

3. First free thoracic segment visible from above. $\ldots \ldots \ldots \ldots \ldots \ldots \ldots \ldots \ldots \ldots$ Iphinoe

- First free thoracic segment fused to the carapace and invisible $\ldots \ldots \ldots \ldots \ldots \ldots \ldots$

4. Carapace with lateral horns, the peduncle of uropods much shorter than rami......Eocuma

- Carapace without lateral horns, the peduncle of uropods much longer than rami.. Bodotria

5. Dorsal plate of the telsonic segment subtruncate posteriorly and not produced between basis of uropods. Third maxilliped with external distal portion of basis produced into a prominent lobe. Peraeopods 2-3 of both sexes with imperfectly developed

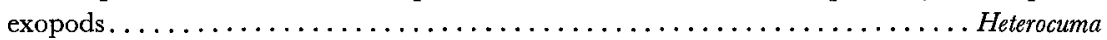

- Dorsal plate of telsonic segment rounded or somewhat angular posteriorly and produced

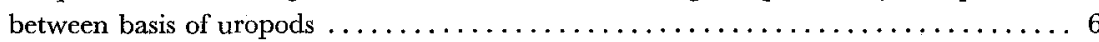


6. Third maxilliped with external distal portion of basis absent or not strongly produced and with ischium short (much wider than long); merus much longer than ischium, but shorter than carpus. Peraeopods 1-4 of male and 1-3 of female with well

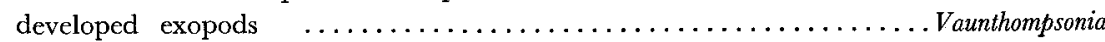

- Third maxilliped with external distal portion of basis prominently produced and with ischium at least as long as wide, nearly subequal in length to merus and carpus.....7

7. Eye present. Pseudorostral lobes not beyond ocular lobe. Peraeopods 1-3 of both sexes with well developed exopods......................... Sypodomma

- Eye absent. Pseudorostral lobes meeting in front of ocular lobe. Peraeopods $\mathbf{1 - 4}$ of male and $1-3$ of female with well developed exopods............. Bathycuma

\section{Genus Bodotria GoodsIR, 1843.}

The Japanese species of the genus hitherto known are all characterised by having the one-segmented endopod of uropods and the first pair of peracopods with broad carpus.

Key to the Japanese species of Bodotria

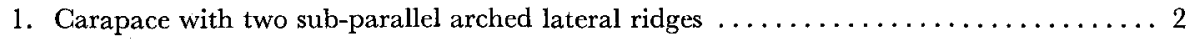

- Carapace with one, or sometimes straight dorso-lateral and lateral ridges $\ldots \ldots \ldots \ldots .3$

2. Dorso-lateral ridge with forwarded small teeth $\ldots \ldots \ldots \ldots \ldots \ldots \ldots \ldots$. serrulata

- Dorso-lateral ridge without small teeth $\ldots \ldots \ldots \ldots \ldots \ldots \ldots \ldots \ldots \ldots$. biplicata

3. Dorso-lateral ridge on carapace partial or faintly marked $\ldots \ldots \ldots \ldots \ldots \ldots, \ldots$. pulex

-. Dorso-lateral ridge on carapace rather well or strongly developed $\ldots \ldots \ldots \ldots \ldots \ldots 4$

4. Dorso-lateral ridge on carapace expanded laterally, forming a clear edge $\ldots \ldots \ldots \ldots 6$

- Dorso-lateral ridge on carapace not so expanded laterally $\ldots \ldots \ldots \ldots \ldots \ldots \ldots \ldots . \ldots \ldots$

5. Carapace very roughly pitted with a fine reticulated background $\ldots \ldots \ldots \ldots$. rugosa

- Carapace with finely reticulated patterns and pitted $\ldots \ldots \ldots \ldots \ldots \ldots \ldots$. similis

6. Carapace not ovoid in shape as seen from above $\ldots \ldots \ldots \ldots \ldots \ldots \ldots \ldots . . \ldots \ldots$ carinata

- Carapace almost ovoid in shape as seen from above $\ldots \ldots \ldots \ldots \ldots \ldots \ldots$. ovalis

\section{Bodotria pulex (ZIMMER)}

Cuma pulex Zimmer 1903, p. 666, figs. A-C.

Bodotria pulex, Stebbing 1913, p. 26; Marukawa 1927, p. 856, fig. 2457.

B. pulex (?), GAMô, 1963a, p. 30, figs. 2-4.

This species was first described as Cuma pulex basing on a single female specimen $3.5 \mathrm{~mm}$ long from Enosima in Sagami Bay, 6-22 m, by Zimmer (1903). The female (3.7 mm long) obtained from Amami-Oshoma Island (about $1 \mathrm{~m}$ deep) by GAMô (1963a) agrees with the Zimmer's original description and figures in the following characteristics: the carapace is furnished with a lateral ridge on the anterior portion and beset with fossete-like sculptures on the surface; the second to fifth free thoracic segments are provided with a well-marked lateral ridge. However it differs from the ZimmeR's figures in that the first peraeopods have a relatively short basis and a very long carpus.

Distribution: Tokyo Bay, Sagami Bay and Amami-Oshima Island. 


\section{Bodotria similis CALMAN}

Bodotria similis Calman 1907, p. 4, pl. 1, figs. 1-9; Fage 1945, p. 108, fig. 6; Kurian 1951, p. 18; 1954, p. 276; GAMÔ 1962b, p. 156, figs. 3-5; 1965c, p. 532, fig. 691.

B. siamensis Calman 1907, p. 5, pl. 1, figs. 10-15; FAGE 1945, p. 181, fig. 7.

B. pumilio ZiMMER 1921b, p. 119, figs. 4-7.

Mature specimens of both sexes from Japan show a great variation in the elevation of the dorso-lateral and lateral carinae on the dorsum of the cephalothoracic portion and on the first two abdominal segments, as well as in the textures on the carapace. The dilated carpus of the first peraeopod also varies greatly in shape and breadth. Some mature males have a faint ridge below the lateral carina on the carapace. The specimens resemble very closely the Calmav's original description and figures (CALMAN 1907), but differ from the latter in having the larger body (3-4 $\mathrm{mm}$ long), the carapace with a less distinct ridge below the lateral carina in male and without such a ridge in female, the relatively longer uropod, and the dilated carpus of the first peraeopod.

The features of the Japanese specimens also resemble very closely B. siamensis and $B$. pumilio, and thus may show an intermediate state between the three species mentioned-above.

Distribution: Sagami Bay, Kii peninsula; Formosa, Vietnam, Gulf of Siam and India (Trivandrum and Andamans).

\section{Bodotria biplicata GAMô}

(Colour Plate fig. 1)

Bodotria biplicata GAMô 1964d, p. 241, figs. 1-3.

This species is very like $B$. pulchella SARs from European waters (SARs, 1879; Stebbing, 1913; FAGE, 1951), but differs from the latter in having the uropod with one-segmented endopod and the basis of the second peraeopod without stout spines on the inner border.

Distribtuion: Sado Island (by night surface tow in Mano Bay).

\section{Bodotria serrulata GAMô}

(Colour Plate, fig. 2)

Bodotria serrulata GAMô 1965a, p. 9, figs. 5-7.

This species is closely allied to B. biplicata, but separable from the latter by the following characteristics: 1) the cephalothoracic portion with strong keeled carinae, 2) the lateral carina with a short transverse ridge, 3) the dorso-lateral and lateral carinae do not bend dorsally and not contact with the reticulated patterns on the 
dorsal surface, 4) the well-developed dorso-lateral ridge is provided with a series of small serrated crest.

Distribution: Akkeshi Bay, sandy mud bottom, 8-12 m, by night sub-surface tow.

\section{Bodotria rugosa GAMồ}

Bodotria rugosa Gamô 1963a, p. 34, figs. 5-7.

The species is easily distinguished from other species hitherto known from Japan by that the carapace is very rugose and roughly pitted, the peduncle of the antennule with a very large basal segment, and the carpus and merus of the first peraeopod are almost rectangular in shape.

Distribution: Amami-Oshima Island, coral sandy bottom, about $1 \mathrm{~m}$ deep.

\section{Bodotria carinata GAMÔ}

Bodotria sp., GAMÔ 1960 c, p. 118, pl. 59, fig. 1 ( 9 coloured).

B. carinata Gamô 1964 b, p. 21, figs. 4-5. $30 \mathrm{~m}$.

Distribution: Sagami Bay (off Manazuru), sandy with shell fragments, about

\section{Bodotria ovalis Gamô}

(Colour Plate, fig. 3)

Bodotria ovalis GAMô 1965a, p. 2, figs. 2-4.

Body length, about $4.2 \mathrm{~mm}$ ( $\delta$ ), $4.8 \mathrm{~mm}$ (우). The dorsal surface of the carapace is very broad and flattened, and the cephalothoracic portion with a pair of strong dorso-lateral keeled carinae is almost ovoid in shape as seen from above. The cephalothoracic portion of the male is rather narrower than that of the female.

Distribution: Akkeshi Bay, sandy mud bottom, 8-12 $\mathrm{m}$ deep, by night subsurface tow.

\section{Genus Iphinoe SPEnCE Bate, 1856.}

\section{Iphinoe sagamiensis GaMô}

Iphinoe sagamiensis GaMô 1958, p. 385, 388, fig. 2; 1960c, p. 118, pl. 59, fig. 3 (ㅇ coloured); 1962b, p. 166, fig. 9 ; 1965c, p. 533, fig. 695.

Distribution: Sagami Bay, Kii Peninsula (Shirahama), Aamakusa.

\section{Genus Cyclaspis G.O. SARS, 1864}

Key to the Japanese species of Cyclaspis

1. Carapace with three forwarded teeth on the dorsal crest C. purpurascens 
- Carapace without teeth on the dorsal carina $\ldots \ldots \ldots \ldots \ldots \ldots \ldots \ldots \ldots \ldots \ldots \ldots$

2. Merus and carpus of the first peraeopod distinctly elongated and slender ....... . bidens

- Merus and carpus of the first peraeopod relatively short and somewhat robust ..... 3

3. Carapace with large swellings (at least on each side in adult $t$, three on each side and smaller tumidities on the dorsal surface in $o$ and immature $t) \ldots \ldots \ldots$. . strumosa

- Carapace without special swelling or tumidities, but clothed with small reticulated shallow pits with a fine reticulated background $\ldots \ldots \ldots \ldots \ldots \ldots$. amamiensis

\section{Cyclaspis bidens Gamô}

Cyclaspis bidens GAMÔ 1962b, p. 163, figs. 7, 8; 1965c, p. 533, fig. 692.

This species is related very closely to $C$. bengalensis KurIan from the Andamans (KuRIAN, 1954), but distinguishable from the latter by the following features: the depth of the carpace is much more than one-half of its length and much more than its width, the basis of the third maxilliped has the external process reaching the middle of the merus, and the first peraeopod has the merus without a tooth-like prolongation on the outer side.

Distribution: Kii Peninsula (Shirahama, by night sub-surface tow.).

\section{Cyclaspis strumosa HALE}

Cyclaspis strumosa HALE 1948, p. 13, figs. 7-9; KurIAn 1954, p. 280; GaMô 1962b, p. 161, fig. 6; 1965c, p. 533, fig. 693 .

Distribution: Kii Peninsula (Shirahama), Amakusa; Western Australia, Queensland; and the Andamans.

\section{Cyclaspis amamiensis GMAÔ}

Cyclaspis amamiensis GaMô 1963a, p. 40, figs. 8-10.

Distribution: Amami-Oshima Island, sandy bottom, about $1 \mathrm{~m}$, and sandy bottom of a small tide-pool near the low tide mark.

\section{Cyclaspis purpurascens GAMô}

(Colour Plate, fig. 4)

Cyclaspis purpurascens Gamô 1964c, p. 192, figs. 2-4.

The present species looks in general appearence like the species of the genus Iphinoe, but it is distinguishable from the latter by that the endopod of the uropod is not two-segmented and that the ischium of the second peraeopod is not fused with the basis.

The species is closely related to $C$. costata Calman and C. picta Calman from Ceylon (Calman, 1904), C. varians Calman from Woods Hole of North America 
(Calman, 1912) and C. carinata Zimmer from the east coast of Africa (Zimmer, 1921b) in the following characters: the pseudorostral lobes meet each other, horizontally projecting out beyond the ocular lobe, and the rami of the uropod are provided with similar armatures. It is easily distinguished from any of the above-mentioned five species by its carapace with three forwarded teeth.

However, the species differs from most species of Cyclaspis in having the larger first free thoracic segment which is nearly fused with the carapace, especially in the female, and also in having the rami of the uropod with stout distal spines instead of ending in an acute apex.

Distribution: Kii Peninsula (Shirahama), sandy mud bottom, about $23 \mathrm{~m}$.

\section{Genus Eocuma Marcusen, 1894.}

Key to the Japanese species of Eocuma

1. Lateral horn of carapace obtuse and rounded $(\delta) \ldots \ldots \ldots \ldots$. amakusensis sp. nov.

- Lateral horn of carapace prominent and acute. . . . . . . . . . . . . . . . . 2

2. Antero-lateral horn of carapace separated from the lateral horn by a deep cavity...... E. hilgendorfi

- Antero-lateral horn of carapace separated from the lateral horn by a nearly straight

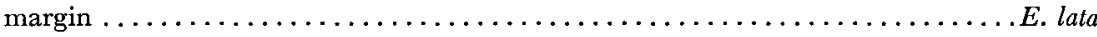

\section{Eocuma hilgendorfi MARCUSEN}

Eocuma higendorfi Marcusen 1894, p. 170; Hilgendorf 1894, p. 171; Stebbing 1913, p. 21; Kurian 1965, p. 181, fig. 1.

E. lata (ㅇ), GaMó 1958, p. 383, 387, fig. 1 (q); 1965c, p. 533, fig. 694.

Distribution: Sagami Bay, Kii Peninsula (Shirahama), Amakusa; India (off Calicut: Kurian, 1965).

\section{Eocuma lata CALMAN}

Eocuma lata Calman 1907, p. 22, pl. 6, figs. 7-12; FAGe 1945, p. 187, figs. 13, 14; Zimmer 1952, p. 14, figs. 16-23; GAMô 1958 , p. 383, 386, fig. 1 (§); 1960c, p. 118, pl. 59, fig. 2 ( coloured).

E. latum, StEbBing 1913, p. 22; KURIAN 1951, p. 96; 1954, p. 285, fig. 3.

Distribution: Sagami Bay; Indo-China (Vietnam), Burma (Tavoy), India (Trivandrum).

Eocuma amakusensis sp. nov.

(Figs. 1-2)

Holotype of adult male (length, $11.9 \mathrm{~mm}$ ): The integument of the body is opaque, strongly calcified and brittle. The surface of the carapace is finely pitted. Under 
a high magnification it is revealed that the carapace is covered with minute shallow pits which are arranged to form a kind of fine reticulated texture (Fig. 2, A). Lateral margins of the carapace and the pleural plates of the thoracic and pleon segments are lamellate, rather opaque, beset with many short striated textures, and fringed with fine hairs.

The carapace is rather depressed and firmly united with the first pedigerous segment. The pseudorostrum is a little in advance of the large rectangular anterolateral horns with round apices. The lateral horns are rather small, situated at the same level as the frontal lobe and well defined by a shallow emargination from the slightly convexed lateral sides of the carapace. As seen from below, a transverse ridge issued from the shallow emargination just behind the lateral horn reaches the free ventral margin of the carapace. The dorso-median carina is faintly marked and becomes rather distinct toward the posterior portion. A pair of dorso-lateral carinae are well marked from the apices of the antero-lateral horns to the hind margin of the carapace. The length of the carapace is more than one-fourth of the total length of the animal, but less than one and a half of the width which is a little more than one and a half of the depth.

The tergite of the second pedigerous (or free thoracic) segment is fused with the first which is firmly united with the carapace, but the second is well defined by a distinct segmentation. As seen from below, the first and second sternites are also fused each other; their side plates are rather developed, each with a longitudinal groove holding the flagellum of the antenna. The dorsal surface of the third segment is short and almost concealed under the posterior portion of the dorsum of the second segment. The side plates of the third to fifth segments are well developed.

The abdomen is a little less than three-fourths of the animal length; the segments are plump.

The first segment of the peduncle of the antennule is robust and a little shorter than the two distal segments measured together. The second is shorter than the third. The main flagellum is three-segmented and the accessory flagellum is very minute.

The basis of the first peraeopod is about four-sevenths as long as the remaining distal segments together ; its external angle is protruded to an acute process and its inner border is met with each other. The carpus is a little longer than the propodus which is nearly twice as long as the dactylus.

The second peraeopod is much smaller, a little shorter than one-sixth of the first. The merus has a protuberance on the distal end.

The peduncle of the uropod is a little shorter than one half of the last abdominal segment, and hairy and setose on the inner border. The endopod is nearly tow and one-third times as long as the peduncle, hairy and setose and with three spaced teeth on the inner border, and with one protuberance at the apical end. The exopod is subequal to the endopod and with many plumose hairs on both lateral borders 


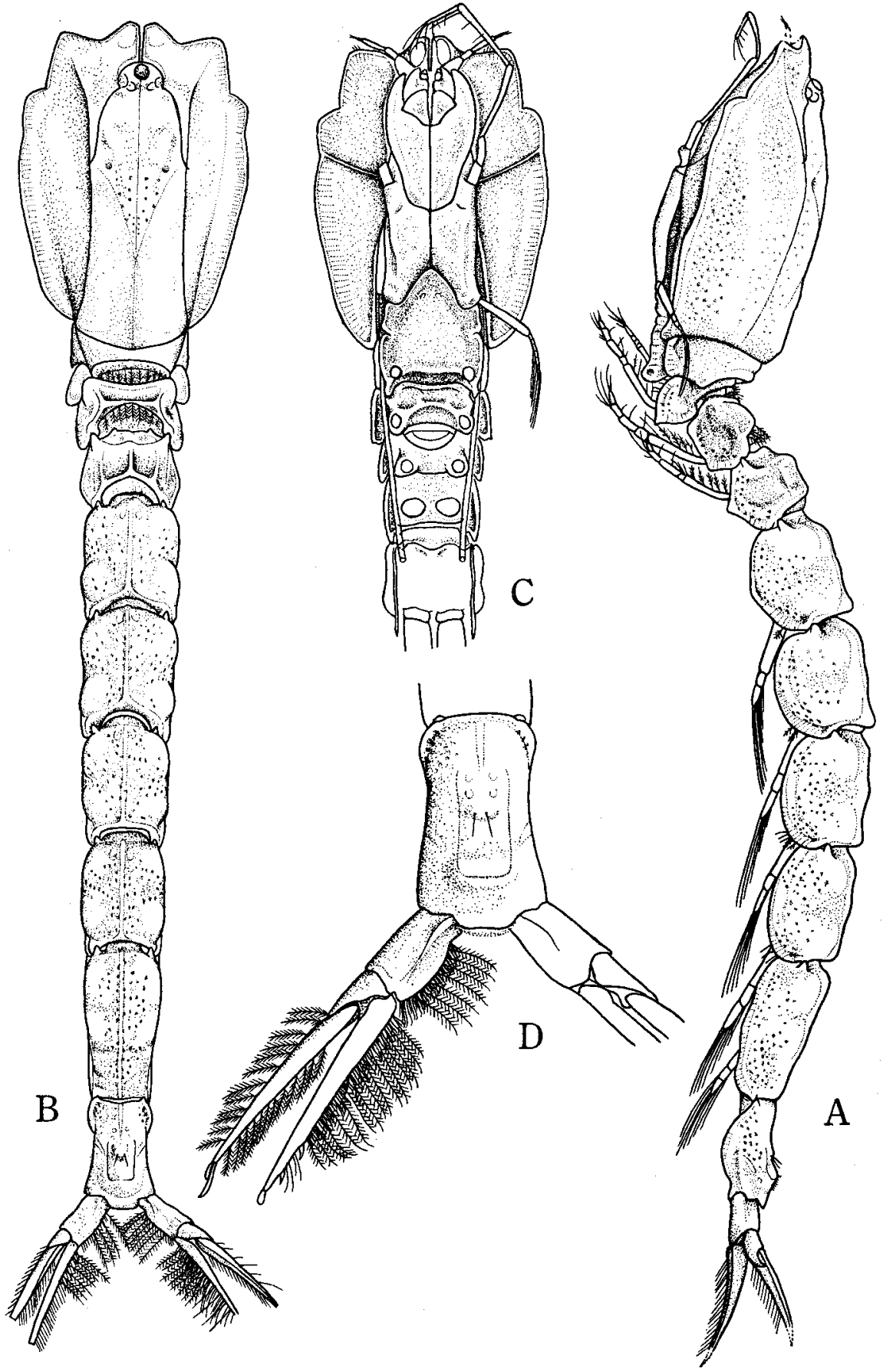

Fig. 1. Eocuma amakusensis sp. nov., holotype adult male (length, $11.9 \mathrm{~mm}$ ): A: lateral vicw. B: dorsal view. $\mathrm{C}$ : anterior portion of body, from below. D: uropod with last abdominal segment. 


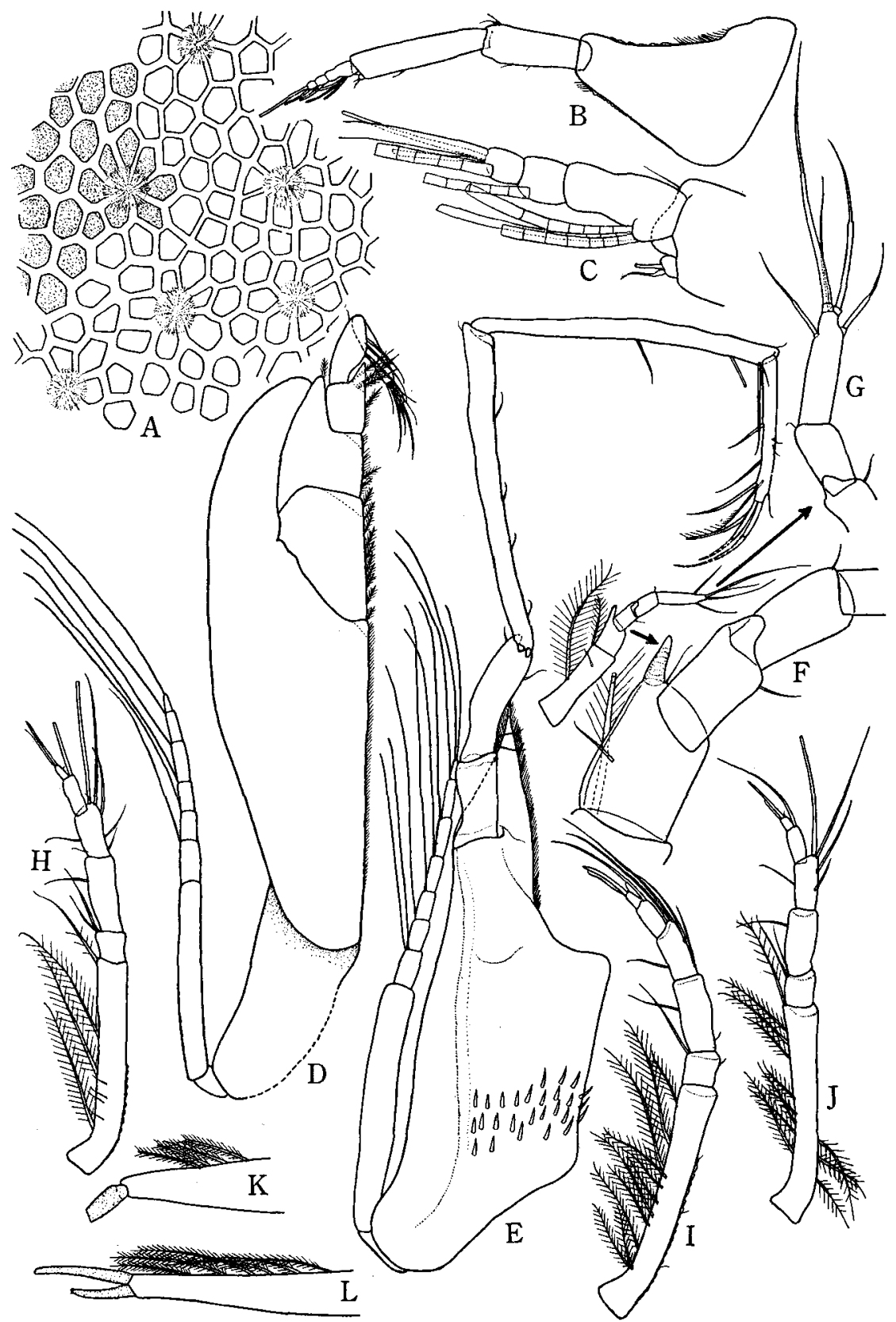

Fig. 2. Eocuma amakusensis sp. nov., holotype adult male: A: texture of carapace surface. B: antennule. C: distal portion of antennule. D: third maxilliped. E-J: first to fifth peracopods. $\mathrm{K}-\mathrm{L}$ : distal portion of exo- and endopods of uropod. 
and two protuberances at the apical end.

Material: 1 o holotype, $4 \hat{\delta}$ paratype, from the muddy bottom of Tomoe Bay near the Amakusa marine biological Laboratory, collected by Dr. KikUTARo BABA on March 19, 1940. The holotype $\hat{\delta}$ and $3 \hat{o}$ paratypes are deposited in the author's collection and 1 s paratype is deposited in the Amakusa marine biological Laboratory, Kyushyu University.

Remarks: The texture of the carapace surface of the present new species resembles closely that of E. stellifera CALMan (1907) from the Gulf of Siam (immature female, $5.6 \mathrm{~mm}$ long); but the former is easily distinguishable from any species of the genus known so far by its unique shape of the antero-lateral and lateral horns of the carapace.

Genus Vaunthompsonia Spence Bate, 1858.

Key to the Japanese species ( $\hat{\delta}$ ) of Vaunthompsonia

1. Carapace of male without dorso-median serrated crest $\ldots \ldots \ldots \ldots \ldots \ldots \ldots$ cristata

- Carapace of male with a dorso-median carina armed with serrated crest ....V. serratifrons

\section{Vaunthompsonia cristata BATE}

Vaunthompsonia cristata, SARs 1879, pl. 12, pl. 23-26; Stebring 1913, p. 13, figs. 5-7; FAge 1945, p. 176 ; 1951, p. 24, figs. 17-18; Zimmer 1952, p. 7, fig. 1; GaMô 1962b, p. 154, figs. 1, 2; 1965 c, p. 532, fig. 688 .

Distribution: Kii Peninsula, Amakusa; British Isles, West coast of France, Atlantic coast of Morocco, the Mediterranean Sea, Indo-China.

\section{Vaunthompsonia serratifrons GAMô}

Vaunthompsonia serratifrons GAMô 1964b, p. 17, figs. 1, 2.

Subadult male (about $4.5 \mathrm{~mm}$ long): The colour of the body is brownish when alive and the integument is rather thin. The species differs from any species of the genus previously described, except for $V$. capensis Zimmer from South Africa (ZIMMER, 1921b), in having the carapace with serrated crest in male. It differs from $V$. capensis in having the obsolete antero-lateral sinus and in showing different proportions of the uropod segments.

Distribution: Sagami Bay (off Manazuru), sandy bottom, about $60 \mathrm{~m}$ deep.

Genus Bathycuma Hansen, 1895.

The following five species have been described. Among them, B. brevirostris is the only species in which both sexes are known, while other species are represented only by either sex. 


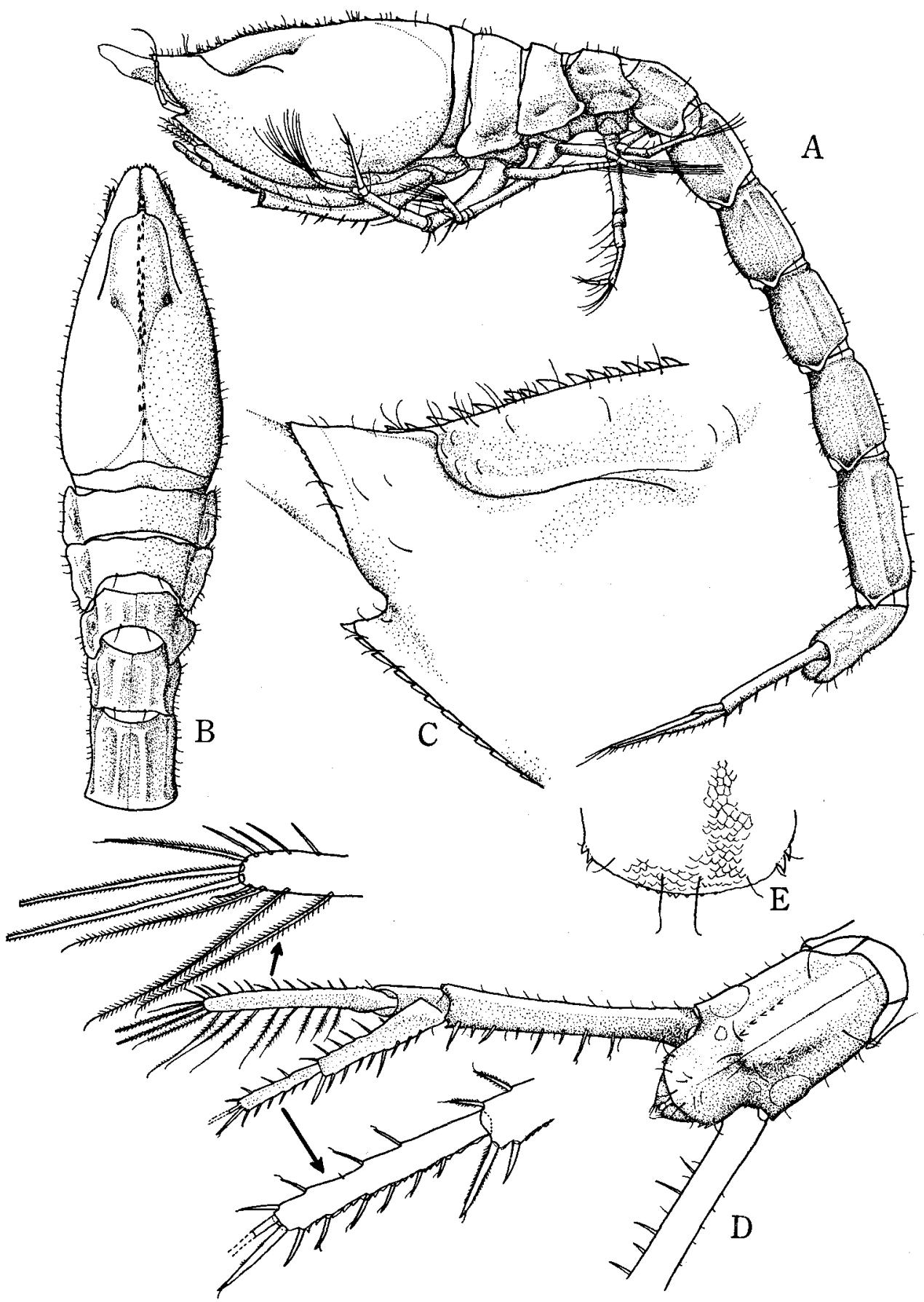

Fig. 3. Bathycuma longicaudata CAlman. Immature female (length, $13.3 \mathrm{~mm}$ ) A: lateral view. B: anterior portion of body, from above. C: anterior portion of carapace, from side. D: uropod with last abdominal segment. E: posterior portion of last abdominal segment, dorsal view. 

B. longicaudata Carman, 1912.: off San Diego, California, 1174-1218 m, o immature, $18.5 \mathrm{~mm}$; $38^{\circ} 57^{\prime} \mathrm{N} \times 9^{\circ} 41^{\prime} \mathrm{E}, 1227 \mathrm{~m}$, ㅇ ca. $9 \mathrm{~mm}$ (StePhensen, 1915).
B. brevirostris (NoRman, 1879).: European waters, 350-1710 m, t and $\$, 8-10 \mathrm{~mm}$.
B. longirostris CALMAN, 1905.: The Malayan Archipelago, $5^{\circ} 40^{\prime} \mathrm{S} \times 120^{\circ} 45^{\prime} \mathrm{E}, 1158 \mathrm{~m}$, ㅇ immature, $12 \mathrm{~mm}$.
B. elongata Hansen, 1895.: The North Atlantic, $18^{\circ} 6^{\prime} \mathrm{N} \times 26^{\circ} \mathrm{W}, 4980 \mathrm{~m}$, o subadult, $12.5 \mathrm{~mm}$.
B. natalensis Stebbinc, 1912.: The Cape Natal, South Africa, $805 \mathrm{~m}$, of $11 \mathrm{~mm}$.

In the present paper, B. longicaudata is newly described from Japan.

\section{Bathycuma longicaudata CALMAN}

(Figs. 3-4)

Bathycuma (?) longicaudata CALmAn 1912, p. 641, figs. 10-13.

B. longicaudatum, Stebbing 1913, p. 12; Stephensen 1915, p. 29.

Immature female with rudimentary incubatory plates (13.3 $\mathrm{mm}$ long): The carapace is nearly one-fourth of the total animal length and less than two times of the depth which is equal to the greatest width. The surface is furnished with scattered short hairs and the dorso-median carina with a pair of longitudinal rows of small teeth pointed forward. The antennal notch is roughly rectangular and the antero-lateral angle is provided with a large tooth at its apex. The lateral or lower margin is serrate. The ocular lobe is rounded to form a very narrow process furnished with two pairs of small teeth, no distinct ocelli; it is one-third as long as the pseudorostrum. The pseudorostral lobes meet each other in front of the ocular lobe and are produced almost horizontally.

The total of free thoracic segments is five-sixths as long as the carapace. The first segment is the shortest. The second to fifth segments are narrowed and decrease the depth successively. On the dorsum of the last two segments there are two pairs of distinct dorso-lateral ridges and a suture-like dorso-median line; the postero-dorsal margin of the last three segments bears a pair of setae. The side plate of the second to fifth segments is prominent.

The abdomen is distinctly longer than one-half of the animal length. The first to fifth segments are each furnished with two pairs of dorso-lateral ridges, a suture-like dorso-median line, and a pair of dorsal setae; on the ventro-lateral side of each segment there is a faintly marked ridge. The first three segments are nearly subequal in length. The fifth is the longest. The last segment is about threefourths as long as the fifth and provided with a suture-like dorso-median line. There is a broad dorsal tumidity with three pairs of setae and about five pairs of small teeth. The posterior portion is protruded, as a prominent round lobe with two pairs of small lateral teeth and three pairs of sub-marginal setae, between the bases of the uropods; it is nearly half as long as the anterior portion.

The first segment of the peduncle of the antennule is elongate and less than the distal two segments measured together. The second segment is a little longer than 


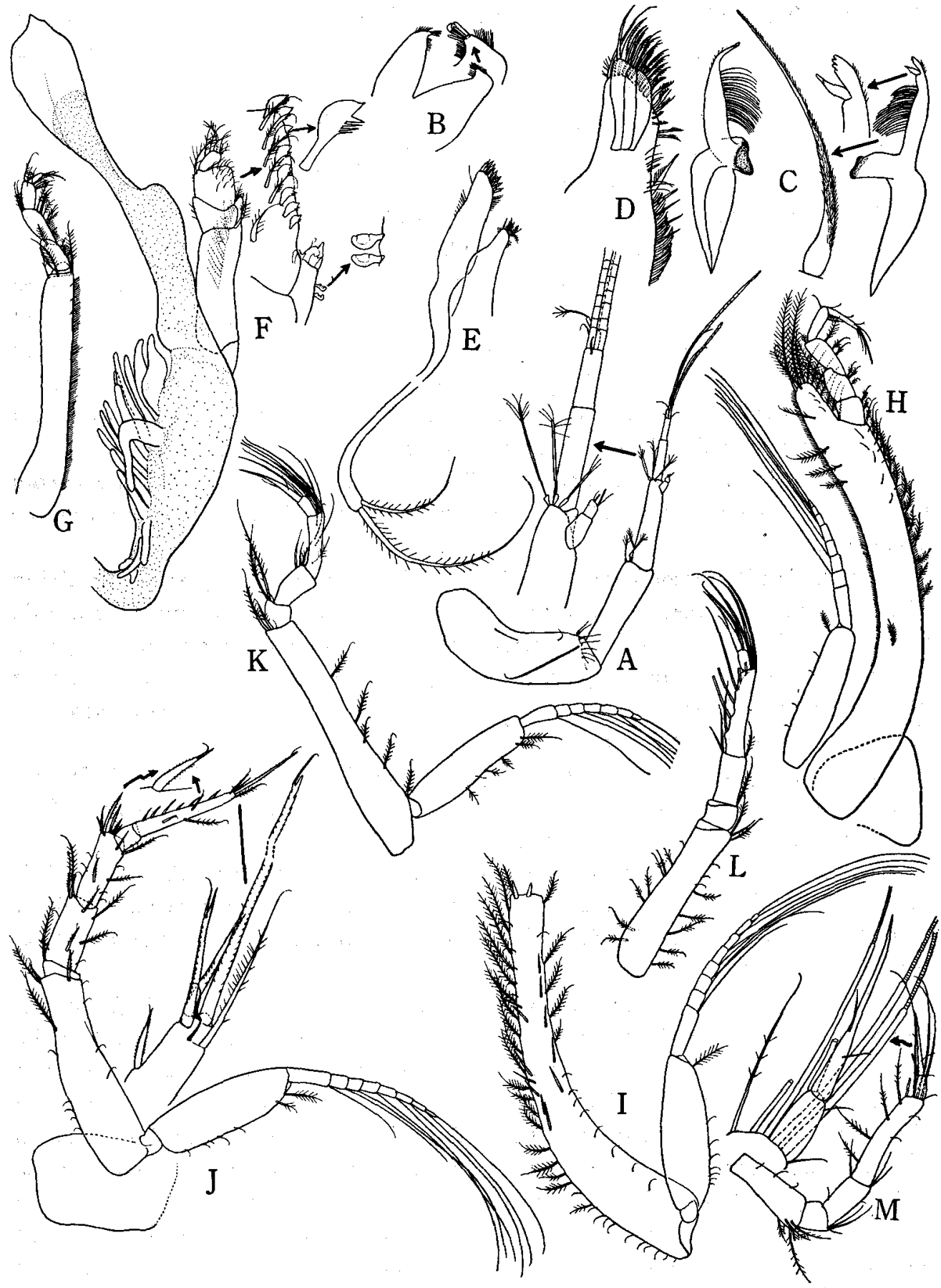

Fig. 4. Bathycuma longicaudata Calman. Immature female: A: antennule. B: labrum. C: mandibles. D-E: maxillule and maxilla. F-H: first to third maxillipeds. I-M : first to fifth peraeopods, 
the third. The main flagellum is two-segmented, with a small protuberance like a segment, and bearing two long subequal aesthetascs. The accessory flagellum is very minute and bears two segments.

The mandible carries twenty-one spines on the right and twenty on the left side. The upper part is a little shorter than the lower.

The labrum, maxillule and maxilla appear as shown in Fig. 4, B, D and E.

The branchial apparatus of the first maxilliped bears sixteen leaflets. The second maxilliped is provided with the slender basis.

The basis of the third maxilliped is rather elongate, a little shorter than three times of the distal segments together, and not widened distally; its distal external angle is produced into a lobe nearly reaching the end of the merus. The inner margin of the basis is not armed with a row of teeth. The ischium is as long as wide, a little shorter than the merus and much shorter than the carpus. The propodus and dactylus are subequal in length and much shorter than the carpus.

The distal portion of the first pair of peraeopods is broken. The basis carries spines on the lower portion of the inner and outer margin and two spines at the distal end.

The basis of the second peraeopod is about three-fourths as long as the remaining distal segments together. The ischium is short and distinct. The merus is a little shorter than the carpus. The dactylus is slightly longer than the carpus and propodus measured together and bears spines and two short setae laterally and a rahter long plumose seta and three unequal spines at the end; one of the distal spines is extremely long, nearly three-fourths as long as the dactylus.

The third peraeopod is slightly shorter than the second. The basis is very elongate and one and one-fifth times the length of the distal segments together. The dactylus is elongate and ending in a claw-like spine.

The fourth peraeopod is about seven-eighths as long as the third. The basis is nearly two-thirds as long as the distal segments together. The fifth peracopod is about four-fifths as long as the fourth; the basis is about one-third as long as the distal segments together.

The peduncle of the uropod is a little longer than the last abdominal segment and provided with five hairs on the outer border and eight unequal spines on the inner border. The exopod is a little shorter than the peduncle, nearly as long as the last abdominal segment; its proximal segment is nearly one-third as long as the distal segment. The distal segment bears nine plumose setae and one short spine on the inner border, thirteen short spines on the outer border, and unequal long plumose setae at the distal end. The endopod is two-segmented, slightly shorter than the exopod. The proximal segment is one and a half times as long as the distal segment and bears nine unequal spines on the serrated inner border and six spines on the outer border. The distal segment bears six spines on the serrated inner border, four on the outer border, and two stout spines at the distal end. 
Material: 1 immature 우, KT 64-17, Plankton Rec-2; $35^{\circ} 6^{\prime} 30^{\prime \prime} \mathrm{N} \times 139^{\circ} 17^{\prime} \mathrm{E}$, Sagami Bay; maximum depth about $1000 \mathrm{~m}$; collected by Dr. M. OмоRI, Ocean Research Inst, Univ. Tokyo on Oct. 25, 1964 (in 16.34-17.45h) by an oblique tow of the ORT-net (OMORI, 1965; Omori \& others, 1965; Aizawa \& others, 1965), $2000 \mathrm{~m}$ wire out. The specimen is deposited in the author's collection.

Remarks: The immature female specimen with rudimentary incubatory plates from Sagami Bay is very closely allied to B. (?) longicaudata Calman (Calman, 1912) in general appearence, but it slightly differs from the latter in its smaller body, the absence of the serrations on the inner border of the basis of the third maxilliped, and in that the dorsal tumidity on the last two free thoracic segments is less distinct, etc. In the present specimen the number of the mandibular spines (20 and 21) and that of the leaflets on the branchial apparatus (16) are rather numerous as compared with the following three species: B. natalensis, B. brevirostris and B. elongata, which have $21,15,17$ spines on the mandible and 8, 5, 8 leaflets on the branchial apparatus respectively.

Distribution: Off San Diego, California, 1174-1218 m (Calman, 1912); South of Sardinia I., the Mediterranean Sea, 1227 m (Stephensen, 1915).

Genus Heterocuma Miers, 1879.

Key to the Japanese species of Heterocuma

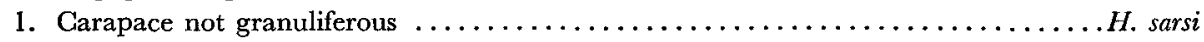

- Carapace granuliferous $\ldots \ldots \ldots \ldots \ldots \ldots \ldots \ldots \ldots \ldots \ldots \ldots \ldots \ldots \ldots \ldots \ldots$ sarsi var. granulata

\section{Heterocuma sarsi MIERS}

Heterocuma sarsi Mrers 1879, p. 22, 58, pl. 3, fig. 3; Hansen 1898, p. 56; Calman 1910, p. 612, pl. 10, figs. 1-13; Stebbing 1913, p. 49; Zimmer 1921a, p. 2; Kurian 1951, p. 105; 1954, p. 294; Gamô 1958, p. 386, 387; 1960c, p. 118, pl. 59, fig. 4 (ㅇ coloured); 1965c, p. 532, fig. 690; HARADA 1964, p. 97 (part).

Distribution: Sagami Bay, Amakusa, the Goto Islets, the Korean Strait; China (Amoy)?, and India (Trivandrum) (KuRIAN, 1951, 1954).

\section{Heterocuma sarsi var. granulata MIERS}

Heterocuma sarsi var. granulata Miers 1879, p. 22, 58; Stebbing 1913, p. 49; Zimmer 1921 a, p. 2; Gamó 1964 b, p. 21 , fig. 3.

H. sarsi var. granulata?, H. granulata, Galman 1910, p. 614.

H. sarsi (part), HARAda 1964, p. 98, pls. 1-2.

Distribution: Sagami Bay, Amakusa, the Goto Islets, the Korean Strait.

\section{Genus Sympodomma SteBbing, 1912.}

Only a single species has been represented from Japanese waters. 


\section{Sympodomma diomedeae (CALMAN)}

Heterocuma diomedeae CALMAn 1912, p. 612, figs. 6-9.

Sympodomma diomedeae, Stebiing 1912, p. 138; 1913, p. 13; Zimmer 1921a, p. 1; Gamô 1958, p. 386, 397; 1965c, p. 532, fig. 689; Harada 1964, p. 99, pl. 3, figs. 2, 3.

Distribution: Sagami Bay, Amakusa, the Goto Islets; sandy bottom, 10-128 m deep.

\section{Family Leuconidae G.O. SARS, 1878.}

Key to the Japanese genera of Leuconidae

1. Pseudorostrum distinct and protruded forwards, with efferent orifice at the front ..... 2

- Carapace truncate anteriorly with the antero-lateral lappets covered backwards; efferent

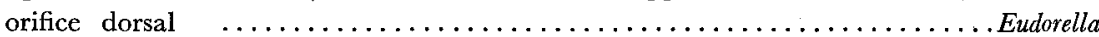

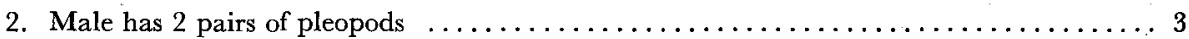

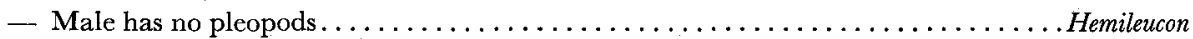

3. First antenna of normal type and not geniculate $\ldots \ldots \ldots \ldots \ldots \ldots \ldots$ Leucon

- First antenna relatively large, flattened and geniculate between the first and the second

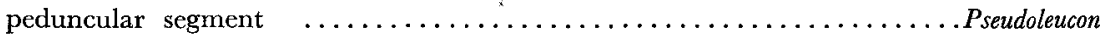

\section{Genus Leucon KRÖYER, 1846.}

Key to the Japanese species of Leucon

1. Body large (longer than $5 \mathrm{~mm}$ in adult female); abdomen much longer than cephalo-

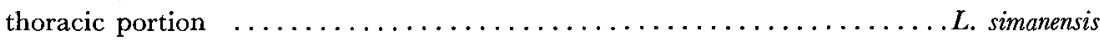

- Body relatively small (shorter than $5 \mathrm{~mm}$ in adult female); abdomen shorter than cephalo-

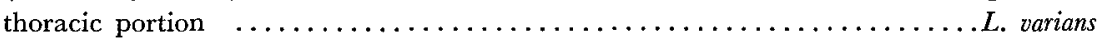

\section{Leucon simanensis GAMô}

Leucon simanensis GAMô 1962a, p. 256, 260, figs. 1, 2.

Distribution: The Lake Shinji (Shimane Prefecture), muddy bottom, 6 m deep.

\section{Leucon varians GAMÔ}

Leucon varians Gamô 1962a, p. 258, 261, figs. 3, 4; 1965c, p. 534, fig. 696.

Distribution: From the brackish water inlet of Tokyo Bay, in the night surface plankton.

\section{Genus Hemileucon Calman, 1907.}

This genus is characterized only by the following male characters: 1) the complete absence of pleopods and 2) the antenna with short flagellum. It is distinguish- 
able from the related genera Leucon and Paraleucon by having no pleopods in the male.

The species previousely referred to this genus are $H$. uniplicata and $H$. comes described by Calman (1907) from New Zealand and $H$. levis described by Hale (1945) from New South Wales. The last differs from the first two in having the uropod with the single-segmented endopod and in lacking lateral ridges on the carapace.

Two more Japanese species assignable to the genus Hemileucon are newly described in this paper.

Key to the species of Hemileucon

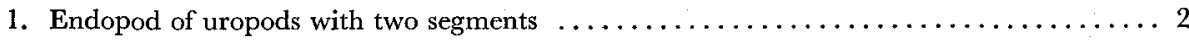

- Endopod of uropods with one segment $\ldots \ldots \ldots \ldots \ldots \ldots \ldots \ldots \ldots \ldots \ldots \ldots$. levis

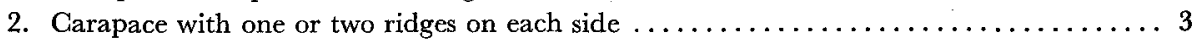

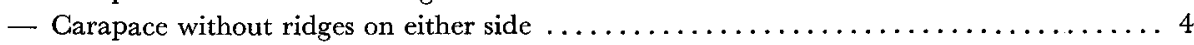

3. Carapace with a single horizontal ridge on each side $\ldots \ldots \ldots \ldots \ldots \ldots \ldots . . . \ldots$ uniplicata

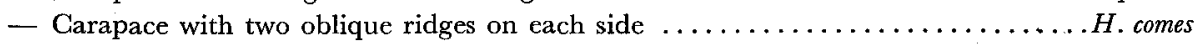

4. Exopod of uropods much longer than endopod. Carapace of female with serrated crest on the anterior portion............................ hinumensis sp. nov.

- Exopod of uropods nearly subequal to endopod in length. Carapace of female without serrated crest $\ldots \ldots \ldots \ldots \ldots \ldots \ldots \ldots \ldots \ldots \ldots . \ldots \ldots . \ldots \ldots . \ldots \ldots$. enoshimensis sp. nov.

\section{Hemileucon hinumensis sp. nov.}

(Figs. 5-7)

Holotype male $(3.7 \mathrm{~mm}$ long): The carapace is rod-like in shape, rounded anteriorly as seen from above. Its surface is rather smooth and without lateral ridges nor carinae. The dorsal outline is slightly arched. The lower margin of the pseudorostrum or the antero-lateral margin is faintly serrate with short hairs. The pseudorostral lobes are very short and a little upturned; its lower margin is somewhat sinuated. The antennal notch is obsolete. The ocular lobe is rather small. The carapace is a little longer than one-fifth of the total animal length and one and twothirds times the width which is slightly less than the depth.

The length throughout the free thoracic segments is slightly more than onefourth of the animal length. Anterior four peraeopods bear the exopod.

The abdomen is rather slender, much more than one half of the animal length and without pleopods on any segment.

The first segment of the peduncle of the antennule is short, nearly as long as the second; the third is slightly longer than the second. The main flagellum is a little longer than the third peduncular segment and four-segmented; the first segment is very long with two subequal aesthetascs; the distal three are short, two subequal aesthetascs at the apical end. The accessory flagellum is minute.

The antenna is short and prehensile.

The basis of the third maxilliped, when measured along the middle line, is one and two-thirds times as long as the remaining disatal segments together; its distal 


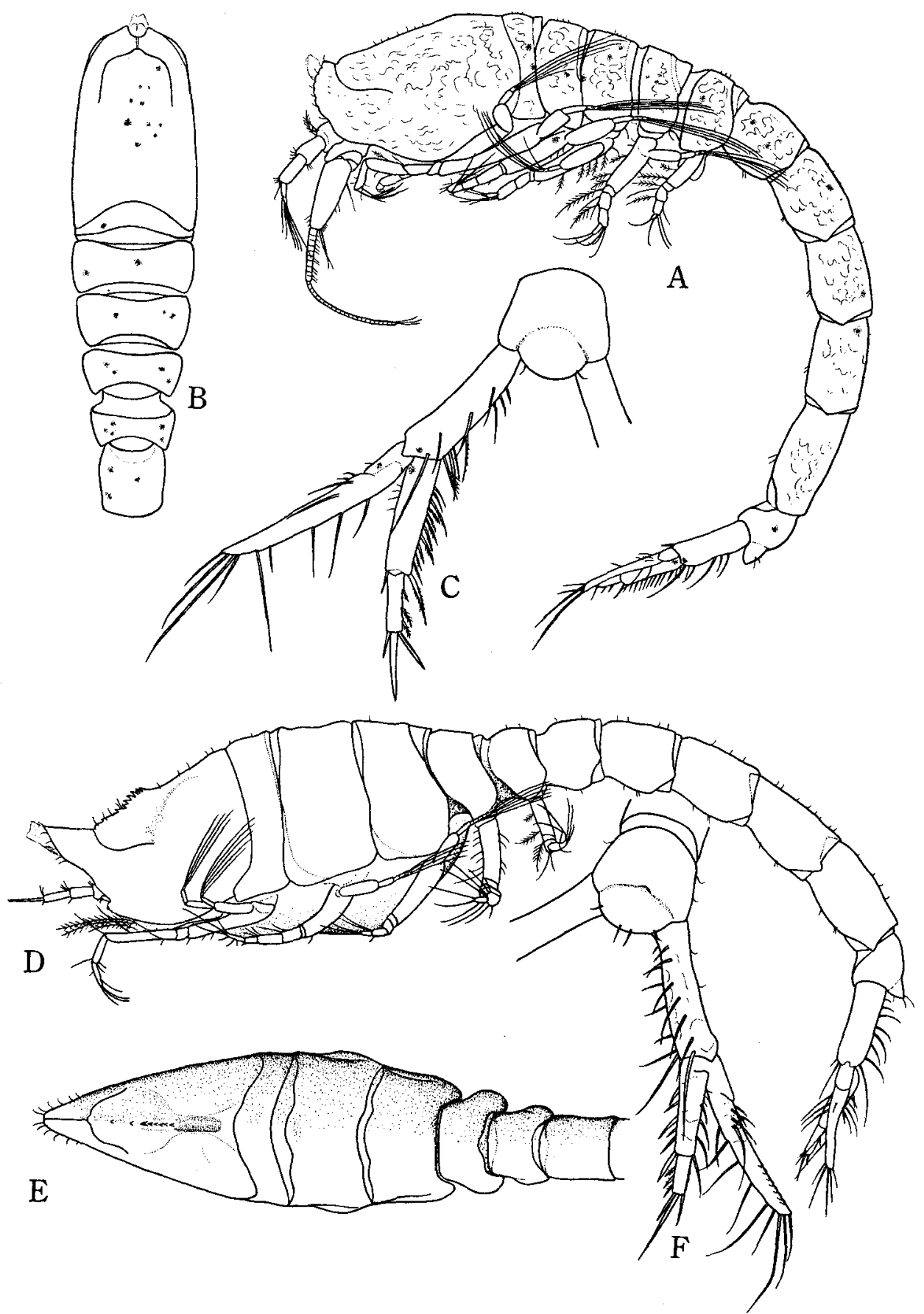

Fig. 5. Hemileucon hinumensis sp. nov., holotype adult male (length, $3.7 \mathrm{~mm}$ ): A: lateral view. B: anterior portion of body, from above. $\mathrm{C}$ : uropod with last abdominal segment. Paratype ovigerous female (length, $2.5 \mathrm{~mm}$ ): D: lateral view. E: anterior portion of body, from above. F: uropod with last abdominal segment. 


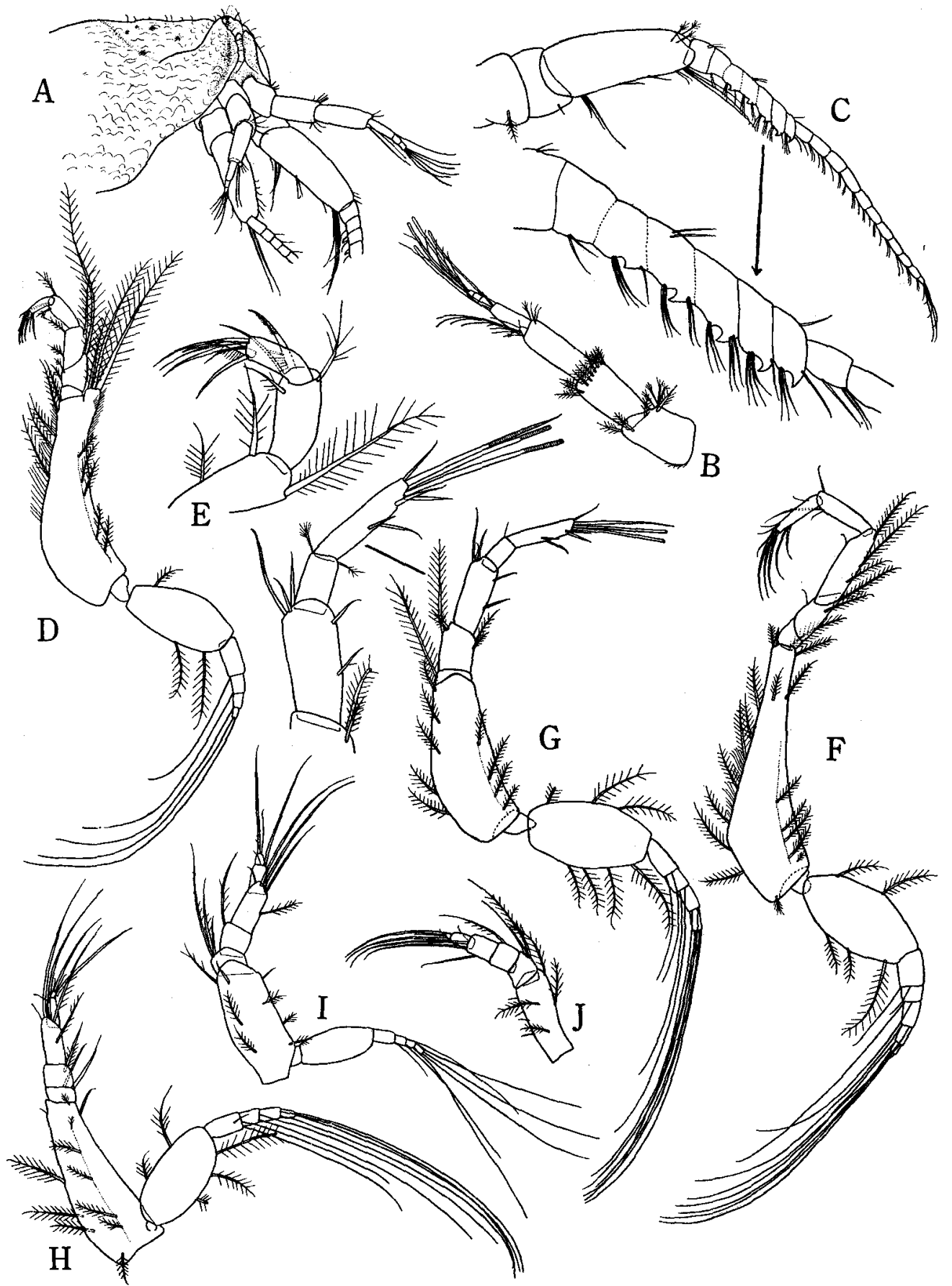

Fig. 6. Hemileucon hinumensis sp. nov., holotype adult male: A: anterior portion of carapace with antennules and antennae. B: antennule. C: antenna. D: third maxilliped. E: distal segments of third maxilliped. F-J: first to fifth peraeopods. 
outer angle is a little protruded.

The basis of the first peraeopod is nearly equal to the total length of the remaining distal segments; the carpus is rather long.

The second peraeopod is nearly three-fourths of the first; its basis is nearly three-fourths as long as the remaining distal segments together.

The peduncle of the uropod is one and one-third times the length of the last abdominal segment; its inner border bears two rows of about ten setae. The endopod is longer than the peduncle and two-segmented; its distal segment is half as long as the proximal. The inner border of the proximal segment is setose or spinose and the distal segment has three plumose spines on its inner border and unequal three apical spines. The exopod is longer than the endopod, slightly curved outward and furnished with rather long setae.

Paratype female ( $5.5 \mathrm{~mm}$ long): The carapace is rather smooth, without lateral ridges nor carinae. As seen from above, the carapace is triangular in shape. A dorso-median serrated crest is prominent on the anterior portion and with a depression near the posterior end. The pseudorostrum is moderately long, pointed and directed obliquely upward. The antennal notch is prominent, with a round antero-lateral corner. The lower margin of the carapace is lightly serrate. The ocular lobe is very small. The carapace length is about one-fifth of the animal length and nearly one and one-third times the width which is a little more than the depth.

The total length throughout the free thoracic segments is nearly one-third of the animal length. The second segment is larger than the others.

The abdomen is a little shorter than a half of the animal length.

The three segments of the peduncle of the antennule are nearly subequal in length. The main flagellum is long, three-segmented, and as long as the distal peduncular segment; the proximal segment is very long, a little less than three-fourths of the length of the flagellum itself. Two subequal aesthetascs are on the distal two segments. The accessory lash is rather large.

The general features of the third maxilliped and the peraeopods are very like those in the male, excepting that the fourth peraeopod is without the exopod. The basis of the first and the second peraeopod is nearly six-sevenths as long as the remaining distal segments together. The second peraeopod is a little shorter than twothirds of the first.

The peduncle of the uropod is one and one-third times as long as the last abdominal segment; its inner border bears two series of about fourteen setae. The endopod is nearly as long as the peduncle and two-segmented; its distal segment is much shorter than a half of the proximal. The proximal segment has six setae or spines on its inner border and four on the outer. The distal segment has three plumose spines on the inner border and three unequal apical spines. The exopod is nearly one and one-fourth as long as the endopod and furnished with rather long setae.

Material: 3 inclusive of the holotype $\hat{\delta}, 8$ 우 ovigerous, and 3 우 with marsu- 


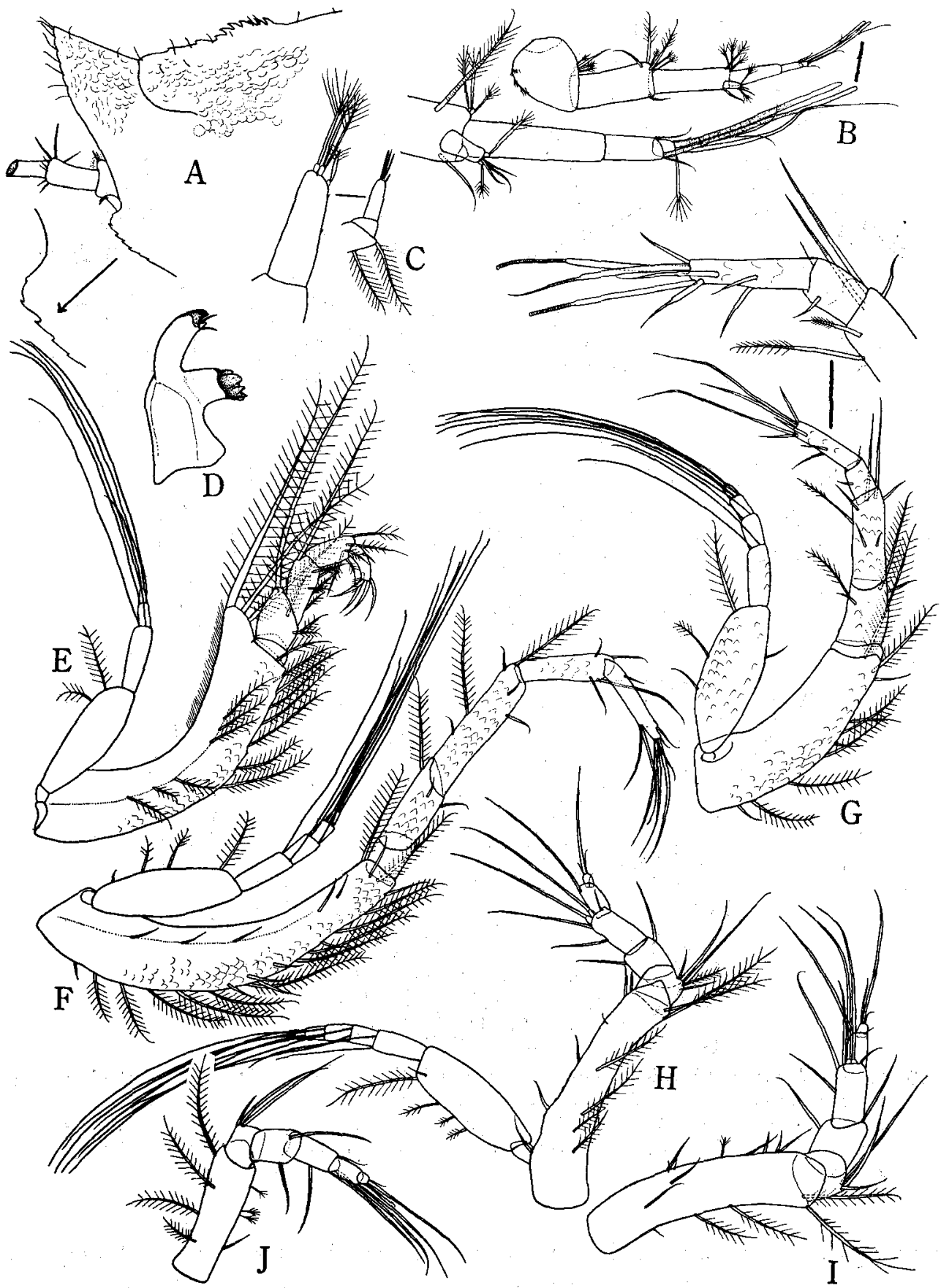

Fig. 7. Hemileucon hinumensis sp. nov., paratype ovigerous female: A: anterior portion of carapace, from side. B: antennule and its enlarged distal portion. C: antenna. D: mandible. E: third maxilliped. F-J: first to fifth peraeopods. 

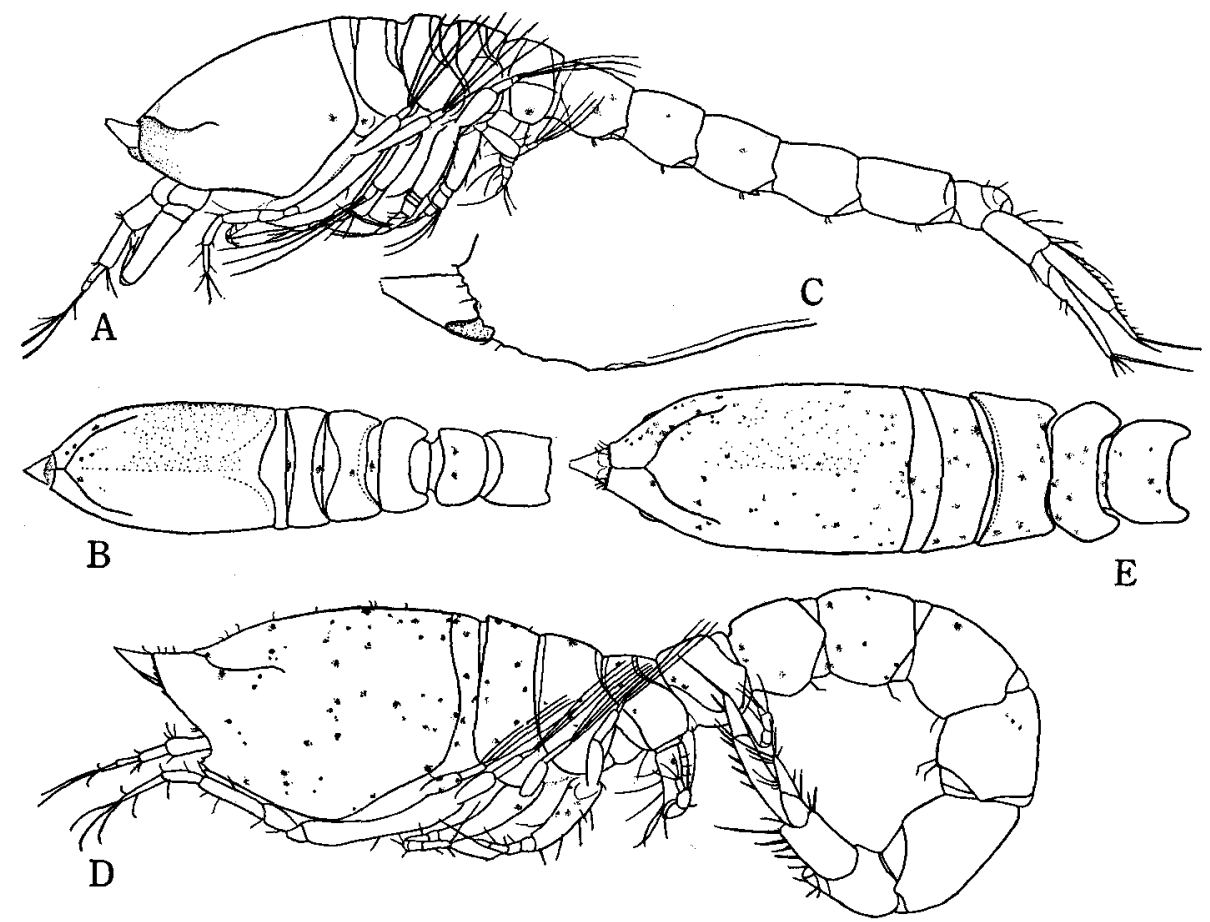

$\mathrm{E}$

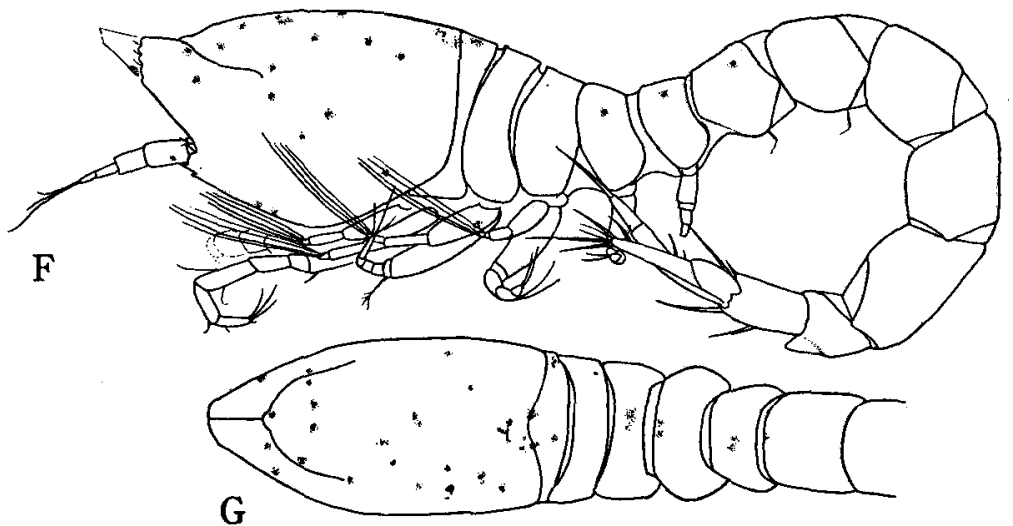

Fig. 8. Hemileucon enoshimensis sp. nov., holotype male (length, $1.8 \mathrm{~mm}$ ): A: lateral view. B: anterior portion of body, from above. C: anterior portion of carapace, from side. Paratype young female (length, $2.4 \mathrm{~mm}$ ): D: lateral view. E: anterior portion of body, from above. Paratype juvenile female (length, $1.5 \mathrm{~mm}$ ): F: lateral view. G: anterior portion of body, from above.

pium; Lake Hinuma, a brackish water lake connected to the open sea through the River Hinuma, Ibaraki Prefecture; coll. Dr. T. Kikuchi on Apr. 4-5, 1963.

Remarks: The differences between this new species and other members of the genus are shown in the key. 


\section{Hemileucon enoshimenses sp. nov.}

(Figs. 8-10)

Holotype male (1.8 mm long): The carapace is smooth. The dorso-median carina is very faintly marked. The dorsal outline is arched. The pseudorostrum is very short, truncated and obliquely directed upward. The antero-lateral margin is very weakly serrate and without antennal notch. The ocular lobe is very small. The carapace is nearly one-fourth as long as the total animal length and one and threefourths times the width which is a little less than the depth.

The length throughout the free thoracic segments is subequal to the carapace.

The abdomen is slightly longer than one half of the animal length.

Three segments of the antennular peduncle are subequal in length. The main flagellum is long, nearly as long as the third peduncular segment, and four-segmented; its proximal segment is the longest, about half as long as the main flagellum. The first and distal segments have respectively two subequal aesthetascs. The accessory flagellum is minute.

The antenna is very short and prehensile.

The basis of the third maxilliped is nearly one and one-third times as long as the remaining distal segments together; its outer angle is a little protruded.

The basis of the first peraeopod is five-sixths as long as the remaining distal segments together.

The second peraeopod is two-thirds as long as the first; its basis is two-thirds of the total length of the remaining distal segments.

The peduncle of the uropod is one and one-third times as long as the last abdominal segment and furnished with two series of eight setae on the inner border. The exopod is one and three-fourths times as long as the peduncle and bears rather long setae on or near the inner and outer borders. The endopod is a little shorter than the exopod and two-segmented; its proximal segment is much longer than two times of the distal; the inner border of both segments bears plumose spines and the apical end of the endopod has three unequal spines, one of which is very long and stout.

Young female (2.4 mm long): The carapace is the same as in the male, without lateral ridges nor carinae; its surface is smooth. The dorsal outline is a little arched. The pseudorostrum is moderately long, horizontally projected forward, and truncated at the apex. The antennal notch is prominent and with a subacute antero-lateral corner which bears three serrations on its outer margin. The ocular lobe is small, almost triangular in shape. The carapace is nearly one-fourth as long as the animal length, a little shorter than two times of the width which is less than the depth.

The total length of the free thoracic segments is nearly as long as the carapace.

The abdomen is much longer than one half of the total animal length.

The peduncle of the uropod is longer than the last abdominal segment; its inner 


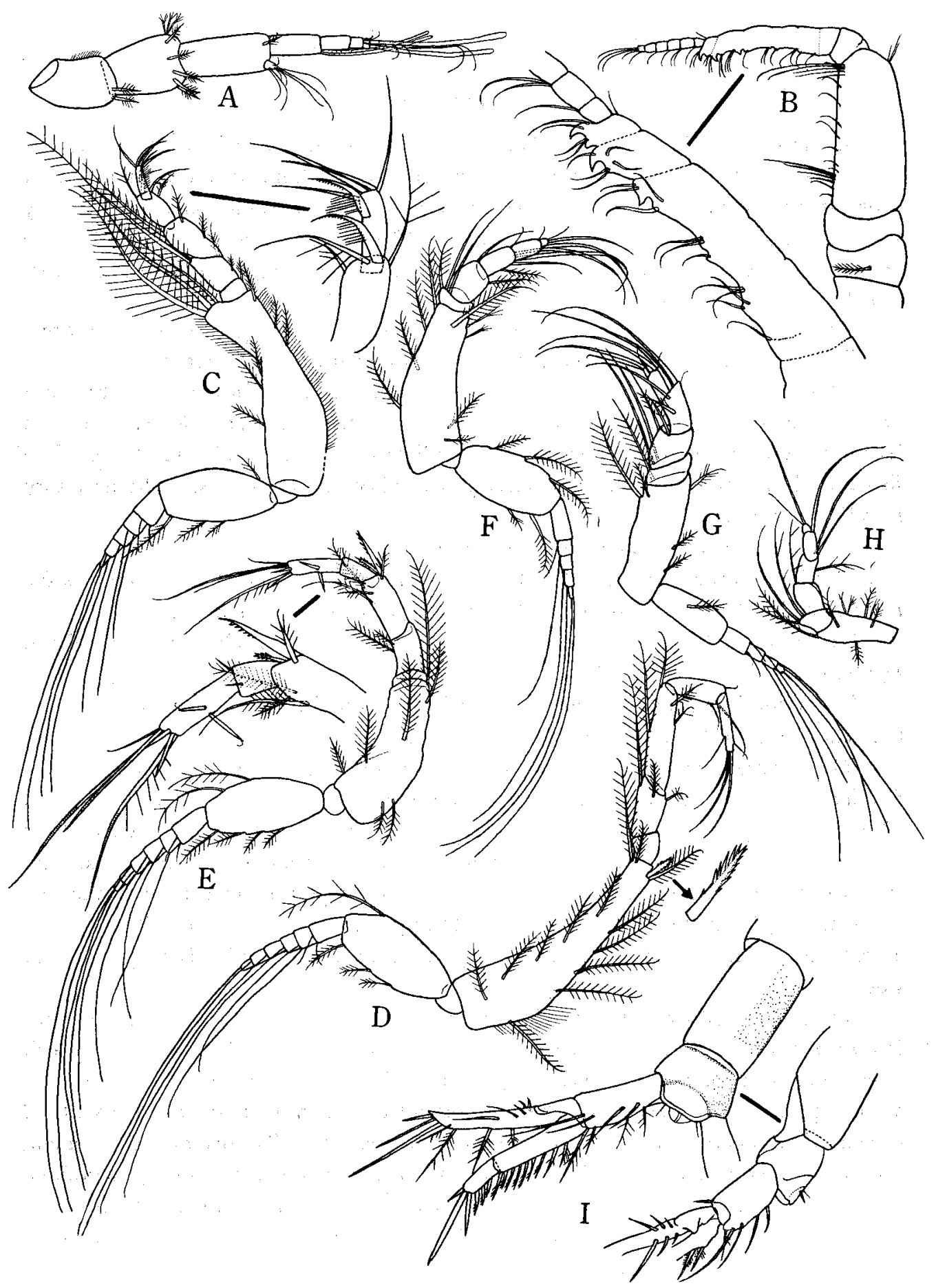

Fig. 9. Hemileucon enoshimensis sp. nov., holotype male. A: antennule. B: antenna. C: third maxilliped and its enlarged distal segments. D-H: first to fifth peraeopods. I; uropod with last two abdominal segments, 


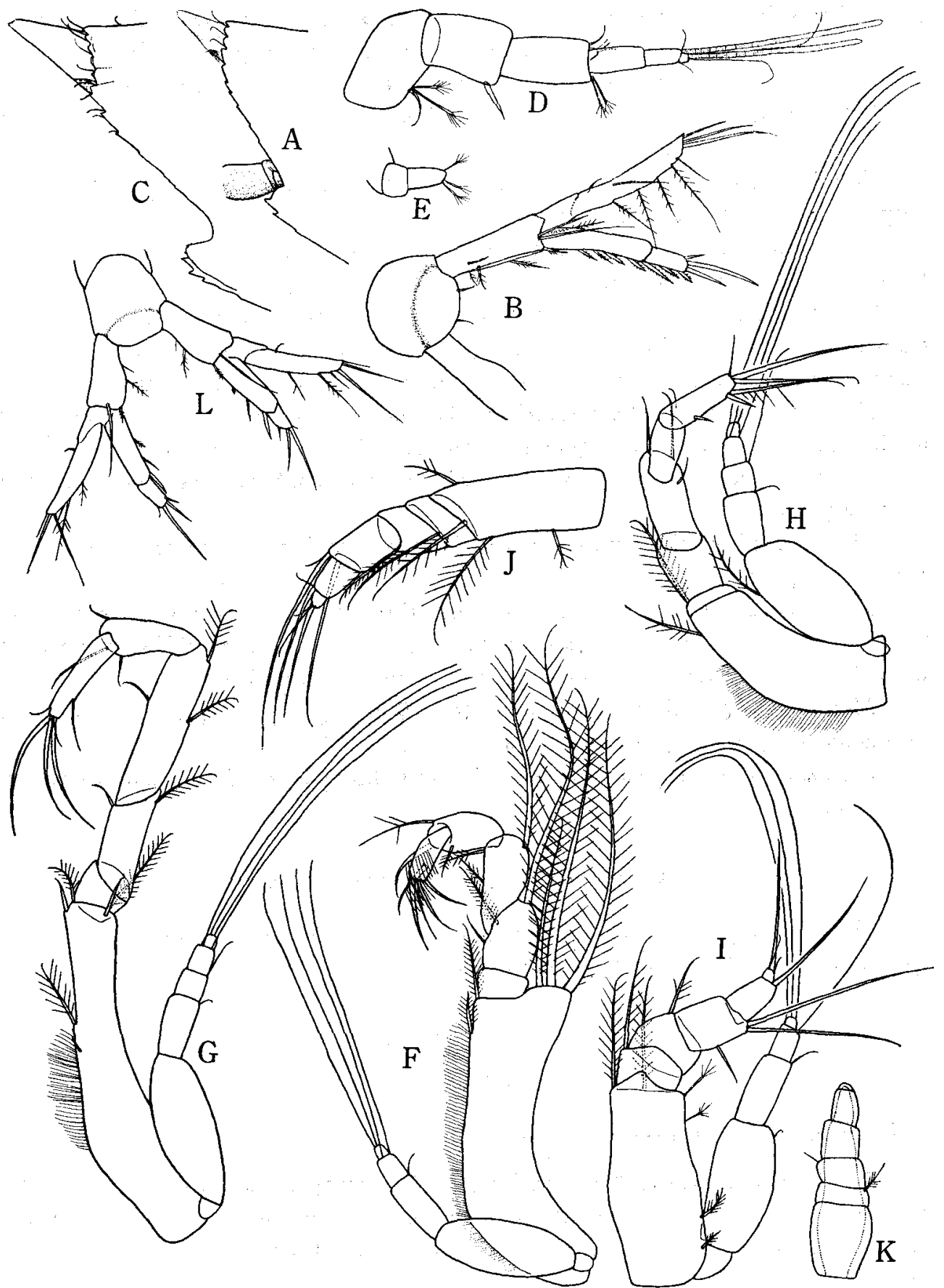

Fig. 10. Hemileucon enoshimensis sp. nov., paratype young female: A: anterior portion of carapace, from side. B: uropod with last abdominal segment. Paratype juvenile female: $\mathrm{C}$ : anterior portion of carapace, from side. D: antennule. E: antenna. F: third maxilliped. G-K: first to fifth peracopods. L: uropod with last abdominal segment. 
border bears four plumose setae. The exopod is a little longer than the endopod, one and half times as long as the peduncle, and bears rather long setae. The endopod is two-segmented; its distal segment is about one-third the length of the proximal and provided with three unequal apical spines; both segments bear each three or four spines on the inner border.

Juvenile female (1.5 $\mathrm{mm}$ long): The carapace and other general features are very like those of the young female.

The combined length of all the free thoracic segments is much less than that of the carapace. The abdomen is nearly half as long as the total animal.

The peduncle of the uropod is shorter than the last abdominal segment. The exopod is one and one-third times as long as the peduncle and the endopod is a little shorter than the exopod. The uropod armatures are not yet fully developed.

The first segment of the peduncle of the antennule is nearly two-thirds as long as the subequal distal two segments together. The main flagellum is three-segmented; the proximal segment is long. There are two subequal aesthetascs on the distal segments.

The basis of the third maxilliped is five-sixths as long as the remaining distal segments together.

The basis of the first peraeopod is nearly three-fourths as long as the remaining distal segments together. The second peracopod is nearly three-fifths of the first; its basis is about three-fourths as long as the remaining distal segments together.

Material: 5 inclusive of holotype $\delta, 1$ 우 young and 1 우 juvenile; Enoshima in Sagami Bay, by a night surface tow on Nov. 11, 1958.

Remarks: The differences between this and other species of the genus are shown in the key.

Genus Eudorella Norman, 1869.

About twenty-five species of this genus have been known, but only a single species is represented from Japanese waters.

\section{Eudorella sp.}

(Fig. 11)

Eudorella sp., GAMô 1965c, p. 534, fig. 698.

Female with marsupium (2.9 mm long): The carapace is one-fifth of the total animal length and one and one-third times the width which is a little less than the depth. The lower half of the anterior portion and the lower margin of the carapace are serrated.

The total length of the free thoracic segments is more than one-fourth of the total animal length. The abdomen is about three-fifths as long as the body. 


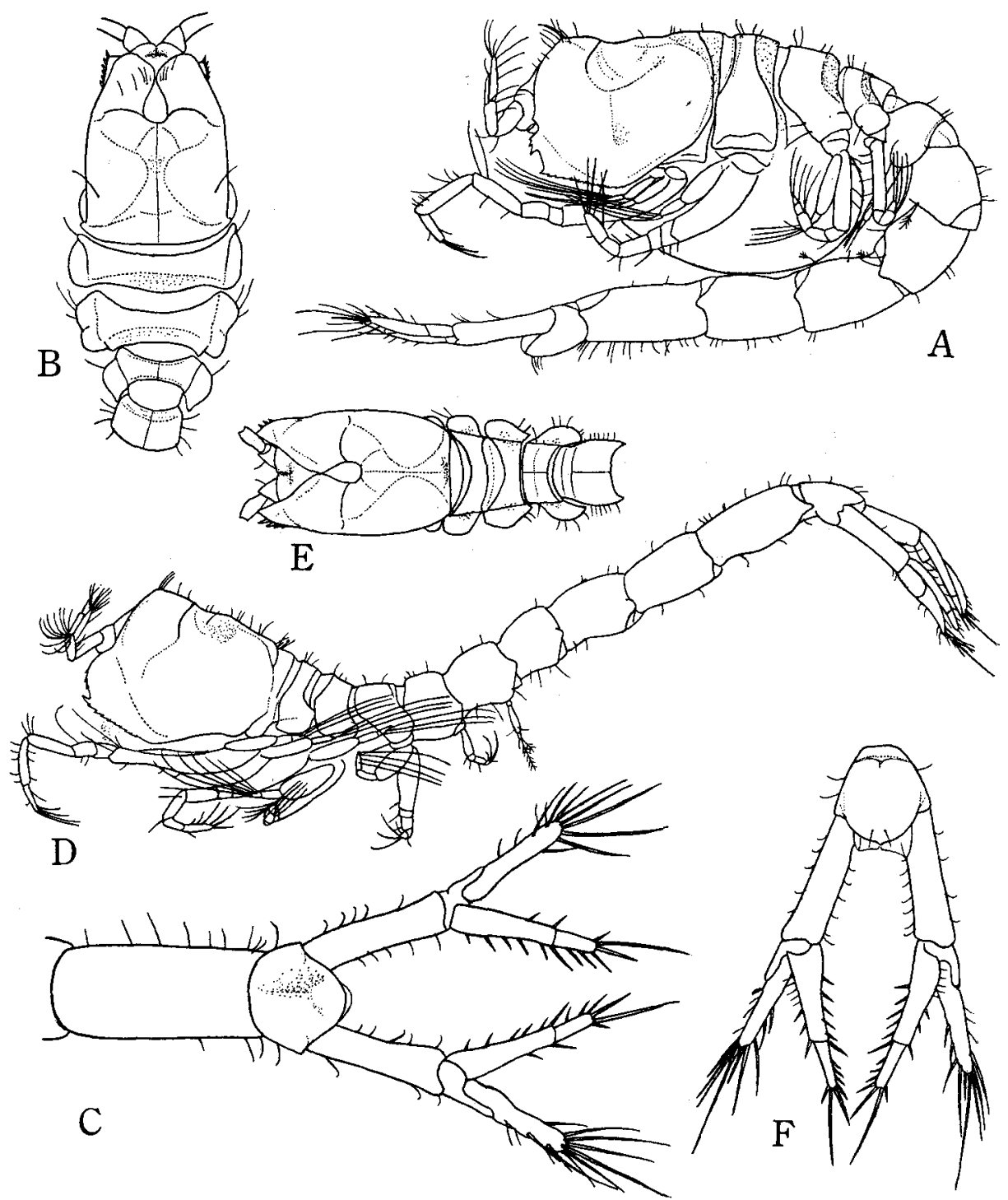

Fig. 11. Eudorella sp., adult female with marsupium (length, $2.9 \mathrm{~mm}$ ): A: lateral view. B: anterior portion of body, from above. C: uropods with last two abdominal segments. Young male (length, $2.6 \mathrm{~mm}$ ) : D: lateral view. E: anterior portion of body, from above. F: uropods with last abdominal segment.

The peduncle of the uropod is one and half times as long as the last abdominal segment. The exopod is nearly as long as the peduncle and bears long setae near the distal margin. The endopod is slightly longer than the exopod and two- segmented; its distal segment is nearly half as long as the proximal and provided with three spines on the inner border and three unequal apical spines at the end. The proximal 
segment bears six spines on the inner and two on the outer border.

Young male (2.5 mm long): The carapace is nearly one-fifth as long as the total animal length and about one and one-third times the width which is less than the depth. The lower half of the anterior portion and the lower margin of the carapace are serrated.

The total length of the free thoracic segments is nearly one-fourth of the animal length. The abdomen is much longer than one half of the body.

The peduncle of the uropod is about one and half times the length of the last abdominal segment. The exopod is a little longer than the peduncle and a little shorter than the exopod. The distal segment of the endopod is nearly half as long as the proximal.

Material: 1 우 and 1 今 (young); off Manazuru, sandy bottom, June 21, 1958.

Remarks: The present form somewhat resembles $E$. pacifica HART, which ranges from the Pcific coast of North America to the Bering Sea, the Sea of Okhotsk and the northern part of the Sea of Japan, although the exact identification of the present specimens is reserved for the future studies on more samples.

\section{Genus Pseudoleucon Zimmer, 1903.}

Of this genus only two species are represented from Japanese waters.

Key to the species of Pseudoleucon

1. Lower or antero-lateral margin of carapace acutely serrate, with intervening setules..

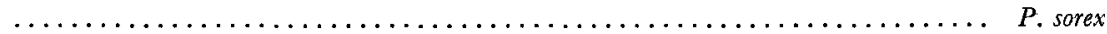

- Lower or antero-lateral margin of carapace not acutely serrate, but cut into squaretoped divisions and thus machicolated $\ldots \ldots \ldots \ldots \ldots \ldots \ldots \ldots \ldots \ldots \ldots \ldots$ japonicus

\section{Pseudoleucon sorex ZIMMER}

Pseudoleucon sorex ZIMmer 1903, p. 676, figs. S-V; CALman 1907, p. 31, 34; Zimmer 1908, p. 176; Stebbing 1913, p. 85, figs. 46-49; Marukawa 1927, p. 856, figs. 245; Gamô 1960c, p. 118, pl. 59, fig. 5 ( ㅇ coloured); 1965 c, p. 534, fig. 697 .

The body (about $4.5 \mathrm{~mm}$ long) is whitish. The lower or antero-lateral margin of the carapace is furnished with acute serrations with intervening setules. The pseudorostrum of the female is acutely projected upwards; the male is very like the female, but its pseudorostrum is very short and truncated.

Distribution: Southern Japan (Tokyo Bay, Sagami Bay), from the muddy bottom of the shallow waters, $6-23 \mathrm{~m}$, or in the night surface plankton.

\section{Pseudoleucon japonicus GAMÓ}

Pseudoleucon japonicus Gamô 1964d, p. 246, figs. 4, 5.

This species is very closely related to $P$. sorex, but distinguished from the latter 
by its different denticulations on the antero-lateral margin of the carapace.

Distribution: Hokkaido and Sado Island; obtained by night surface tow or from the muddy bottom of the shallow waters.

(To be continued) 